\title{
A Z- és az alfageneráció tanulási szokásai, matematikai szempontból
}

\section{Pintér Marianna}

Forrai Művészeti Szakközépiskola és Gimnázium, Budapest

\begin{abstract}
Ennek a cikknek a témája az iskolai tanulás-tanítási folyamat egy aktuális problémájával hozható kapcsolatba.

A szokásos tanulás-tanitási megközelítésektöl eltérően azonban nem általános, hanem speciálisan matematikai szempontból közelítjük meg a Z-és az a-generációhoz kapcsolódó problémát. Nem állitjuk, hogy a játékok és a digitálistananyag-használat automatikusan és okvetlenül didaktikai hasznot hozhatnak vagy áthidaló szerepet játszhatnak ebben a kérdéskörben. Érdekesnek tartom azonban ennek vizsgálatát néhány tananyagrész, néhány eszköz és néhány digitális taneszköz kapcsán, különös tekintettel a motiváció kérdésére, az új tanári szerepre, a „függetlenebb tanulás” utáni vágyra, az együttmüködésre törekvésre.
\end{abstract}

Kulcsszavak: IKT, Z-generáció, a-generáció, játék, matematika

\section{A Z- és az a-generáció}

Az informatikai eszközök - asztali gépek, notebookok, táblagépek, okostelefonok elterjedése (különös tekintettel az érintőképernyős verziókra) és az egyre gyorsabb, szélessávúinternet-hozzáférés elterjedésével kialakult a Z- (1995 után születettek) és az a-generáció (2010 után születettek). Ők azok, akik a tényleges írás-olvasástudás előtt tesznek szert IKT-kompetenciára, már 3-4 évesen elkezdik aktívan használni a digitális eszközöket, hogy a legújabb játékokkal játsszanak, képeket, videókat nézegessenek.

A médiahasználat jelentőségét jól bizonyítják 2006-ban elvégzett magyar kutatások (Pintér és Székely, 2006; Székely, 2006), illetőleg a 2013-ban - a pécsi egyetem Kommunikáció- és Médiatudományi Tanszéke által - elvégzett kvalitatív kutatások. A tanulmányok szerint a középiskolás diákok átlagosan napi 6-7 órás digitálismédiahasználatról számoltak be (Guld és Maksa, 2013).

A Z-generáció jellemzésekor a korosztály legfőbb jellemzőjének a korábbi generációktól való elkülönülést tartják. A magyar szakirodalomban, az ifjúságkutató Székely Levente és Prensky nyomán - a következő ismérvek mentén jellemzi ezt a korosztályt:

- "gyorsan befogadják az információkat,

- az információkat párhuzamosan dolgozzák fel, tevékenységeiket szimultán végzik (multitasking),

- a szöveg helyett a képet és a hangot preferálják,

- előnyben részesítik a véletlenszerü kapcsolódásokat (hypertext),

- kitünően dolgoznak hálózatban,

- vágyaik azonnali és gyakori kielégítésére törekszenek,

- előnyben részesítik a játékot a „komoly” munka helyett,

- a technológiában a kényelmetlen, de szükségszerú társ helyett, barátot látnak" (Székely, 2010. 44. o.).

A nemzetközi szakirodalom szerint a négy legfontosabb ismérvük:

Tanúi voltak a digitális szerkezetek és a digitális technológiák elterjedésének, 
versengenek a figyelemért, fontos számukra a társadalmi felelősségvállalás, állandóan kapcsolatban akarnak lenni mindenkivel.

Az őket követő alfageneráció tagjai lesznek azok a kisiskolások, akik számára még inkább elavultnak tűnnek majd a „szokásos” iskolai információátadási minták. Még jobban zavarja majd őket a „statikus” tananyag, mert nincsenek hozzászokva, hogy csak és kizárólag befogadók legyenek, hogy „magoljanak”, nem szívesen mondanak le az aktív közreműködésröl és az azonnali kommunikációról.

Az igények és az iskola igényei - már a Z-generáció tagjainál is - megfigyelhetően eltérnek egymástól, ezért csak küzdelem árán vonhatók be a hagyományos tanítás-tanulás folyamatba.

\section{Az új tanári szerep}

Elsősorban az új tanári attitüd megjelenése lenne a legfontosabb, hiszen a tanóra légkörét ez nagymértékben befolyásolja. A magas szintű szakmai felkészültségről, a folyamatos önfejlesztésről, a továbbképzés igényéről, a következetességről, az empátiáról most nem ejtünk szót, hiszen ez a klasszikus tanári attitűdnek is része.

Viszont új elemként kiemelendő a tanuló- és nem a tanárközpontú tanulás, a pedagógiai reflektivitás, a személyes tulajdonságok közül pedig a humorérzék, valamint a rugalmasság. Szükséges lenne, hogy az oktatók képesek legyenek az új oktatási formák elsajátítására és használatára.

Az óra menetét a tanárnak kell kézben tartania, de semmiképpen sem mindent tudóként kell végig „uralnia” a helyzetet, sokkal inkább facilitátorként kellene müködnie. Azonban nem csak az óra vezetésében kell új szemléletet kialakítani, hanem a generáció sajátosságai miatt, egyre nagyobb szükség van a változatos munkaformák használatára is. A legújabb kutatások szerint ugyanis, a tanulók igen rövid ideig tudnak csak koncentrálni, ezért szakmailag indokolt egy órán többször is munkaformát váltani. A frontális munkát célszerü párokban megoldható feladatoknak követnie, vagy a füzetben egyéni munkával megoldani egy érdekesnek gondolt gyakorlatot. Esetleg rávenni őket arra, hogy az osztály elé kiálljanak és a táblánál végezzenek el egy-egy feladatot.

A Z- és az a-generáció tagjai nyitottak a felfedeztetve tanítás eszközeire. Éppen ezért szeretik a következő kérdéseket: „Mindenki így gondolja, ez a/az ... jó? Mire gondolhatott Zoli akkor, amikor..., Vajon miért nem lehet, ..., Mit jelent az, hogy, ...., Mi következik abból, hogy..." és a hasonló kérdezve oktató mondatokat.

A tanár-diák reflexió az „egymásra figyelést” is fokozza. A digitális generációnak rendkívül lényeges, hogy a véleményükre kíváncsi legyen a felnőtt, és az órai keretek között kell megteremteni a lehetőséget arra is, hogy egymás véleményét is meghallgassák (Tari, 2011.). Eszmét cserélhetnek például egy-egy bizonyítás, vagy egy-egy diszkutálható feladat kapcsán. Fontos lenne, hogy megfelelően tudják kifejezni magukat a matematikai szaknyelv használatával, továbbá, hogy képesek legyenek mások gondolatmenetébe beilleszkedni. Vegyék észre saját, vagy társuk tévedését, tudják a saját hibájukat javítani, a megoldásuk mellett érvelni. Szükséges a rendszeres viszszajelzés is a tanulók felé, mind az esetleges hibák javítása, mind pedig az önbizalom növelése, és a kommunikáció fenntartása érdekében.

Ha ezek a szempontok előtérbe kerülnek a tanórák tervezésekor, esély van arra, hogy az együttmüködés megvalósuljon. 


\section{Néhány digitális eszköz, illetve játék használata matematikaórán}

A digitális tananyagok beépítése mindkét fél - a tanár és a diák - számára egyaránt kielégítő megoldást jelenthetnek a generációk ( $Z$ és $\alpha$ ) tanulással kapcsolatos problémáira. A digitális tananyagon persze nem a digitalizált tankönyvek kivetítését értjük. Ezzel próbálkozni teljesen felesleges!

Nem gondolom, hogy a digitális tananyag teljes egészében felválthatná az analóg anyagokat. Sokkal inkább amellett érvelek, hogy értelmes módon használva erősítse, és kiegészítse azokat.

\section{Néhány egyszerű példa a digitális anyagok, illetve a játékok felhasználási lehetőségére matematika tanórákon és otthon.}

Az interaktív tábla felhasználásával végezhetünk mozgással gazdagított frontális feladatmegoldást.

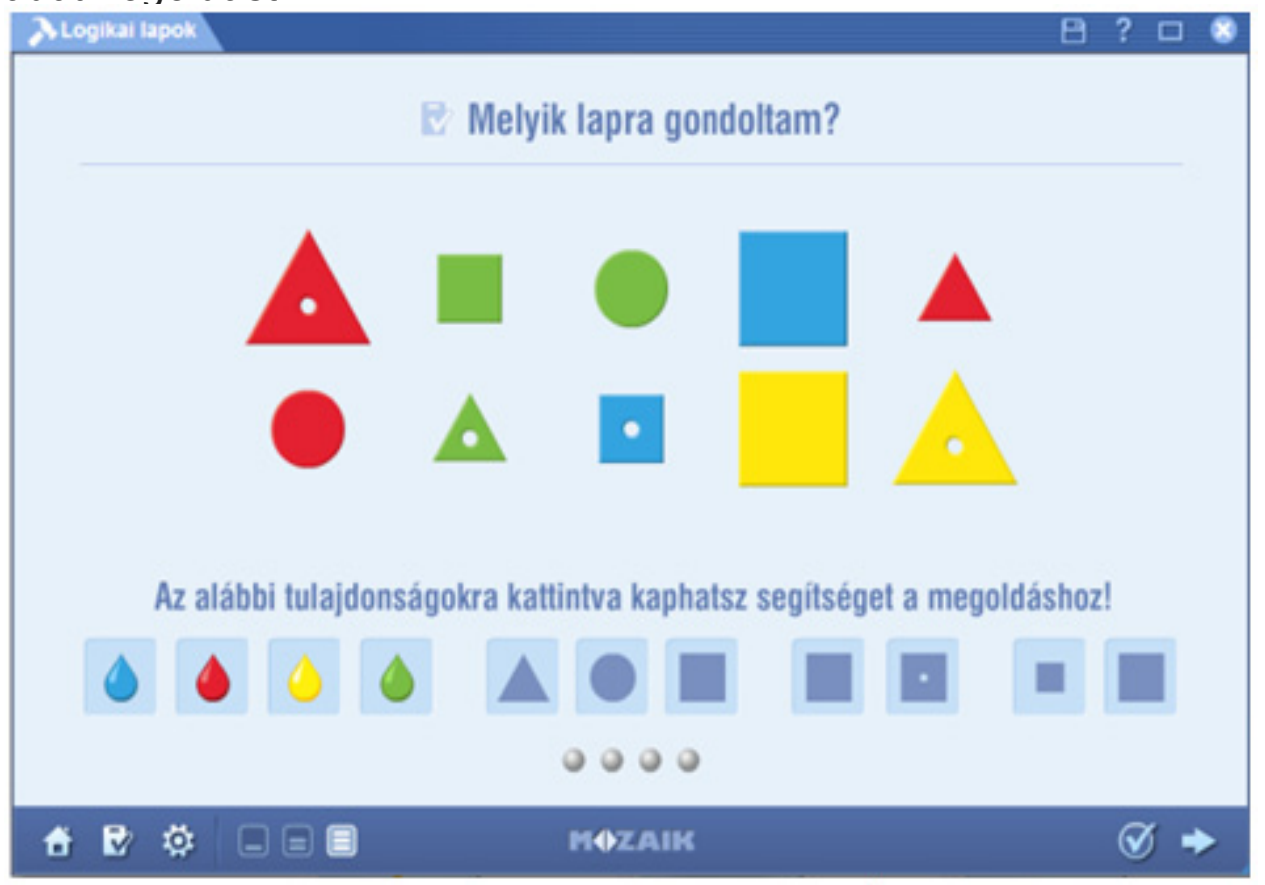

1. ábra: Interaktív tábla
Ez a feladat egy klasszikus barkochba játék.

A játék során a halmazszemléletét és logikai készségét fejleszthetjük az alsós tanulóknak. Sokféleképpen lehet ezt a játékot játszani. Javaslom a mozgással bővített verzióját. Mivel a gyerekek nem képesek hosszan - átla-

gosan hét percnél tovább - koncentrálni, lelkesíti őket az a lehetőség, ha felállhatnak a helyükről. Jelentkezés és felszólítás után egy-egy gyermek kiszalad a táblához, és „kiválasztja” a kérdését. Ő döntheti el, hogy színre, formára, méretre vagy teliségre kérdez-e rá.

Adhatunk a gyerekeknek - szintén az interaktív tábla felhasználásával - olyan feladatokat (például stratégiai játékok), ahol egymás ellen „játszhatnak”. A motivációt a feladat elvégzésére az is adhatja, hogy mindig a győztes játékost lehet kihívni a következő körben.

De adhatók a gyerekeknek internetes házi feladatok is, amivel szintén lehetőséget teremtünk arra, hogy közelebb hozzuk a gyermekhez a tananyagot. Illetve az elkészült házi feladat bemutatásakor, lehetőséget teremthetünk a gyerekeknek a prezentálás gyakorlására, illetve a szaknyelv használatára. Ezek a feladatok lehetnek matematikatörténethez kapcsolódó feladatok, amelyek egy-egy személynek (pl.: Erdős Pál, Varga Tamás), egy probléma történetének (pl.: nagy Fermat-sejtés, ma már tétel) vagy egy időszaknak (pl.: Püthagoreusok) a bemutatását kérik. A prezentáció- 
készítői és -előadói képességek fejlesztésén túl, az ilyen munkáknak szemlélettágító, ismeretszerző, és ismeretterjesztő funkciói is vannak.

Egy ilyen házi feladat témája lehet továbbá egy-egy rendszerező munka is. Például síkgeometriai tanulmányok során egy-egy gyerek megbízható különféle feladattal, „mutassa be a háromszögeket”, „készítse el a családfájukat”. Azaz csoportosítsa a háromszögeket.

Egészen speciális esetben az internetes házi feladatok lehetnek otthoni gyakorlásra elkészített digitális tananyag egységek is.

Az otthoni gyakorlást már nem csak az jelentheti, ha a gyermek tollal vagy ceruzával old meg feladatokat. Egy új forma lehet a digitális gyakorlás például táblagépen. Nem gondolom, hogy a papírral és ceruzával történő számolást fel kellene váltani a digitális formának! Sőt! De azt gondolom, hogy a bevésés folyamatát a digitális kor gyermekeinél megkönnyíti, ha nemcsak papíron végzünk el néhány unalmas gyakorlófeladatot, hanem játék formájában a táblagépen is.

Néhány izgalmas minta otthoni gyakorlásra:

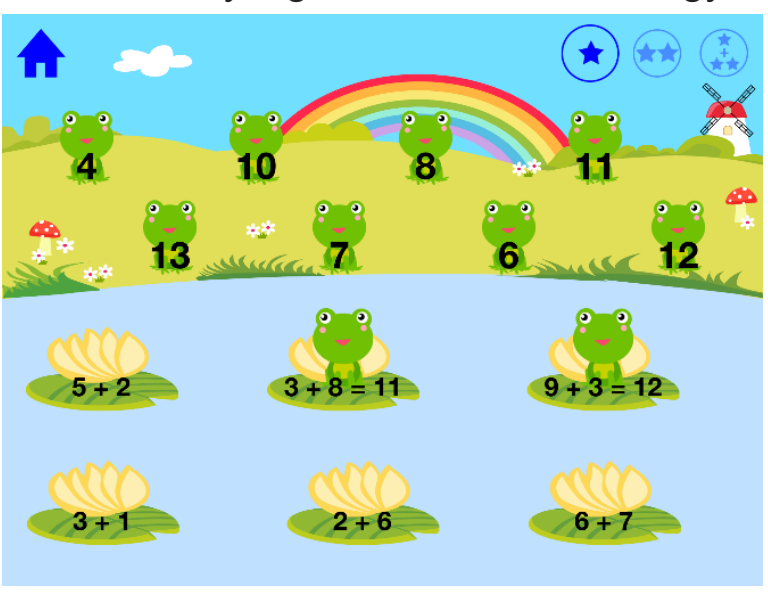

2. ábra: Math is fun (Ages 6-7)

Ez az egyszerü feladat akár az első, vagy a második évfolyamon feladható lenne, gyakorlás céljából. Néhány összeadást kell elvégezni tízes átlépéssel. A feladatban a tavirózsák mozognak, a békák pedig várják, hogy a megfelelő virágra helyezze a gyermek őket. A feladat elvégzéséhez nem elég az összeadást elvégezni. Szükség van a gyors müveletvégzés mellett megfelelő szem-kéz koordinációra és jó reflexekre. Továbbá fejleszti a mintafelismerési és fejbenszámolási képességet, és gyakoroltatja a müveleti jelek felismerését is.

Ez az angol nyelvű (japán fejlesztésű) játék összetettebb az előzőnél. Ilyen nehézségü játékokat már második, még inkább harmadik osztályosoknak javasolnék.

Itt nem az összeget kell az összeadandókhoz hozzárendelni, hanem az összeghez kell kiválasztani a tagokat. Az egyszerübb pályákon még nem lépünk ki a 100-as számkörből, azonban a feladatot tovább nehezíti, hogy a kis sushik közül több módon lehetséges az adott összegeket kialakítani.

A nehezebb pályákon már átlépjük a százas számkört, és egyre több összeadan-

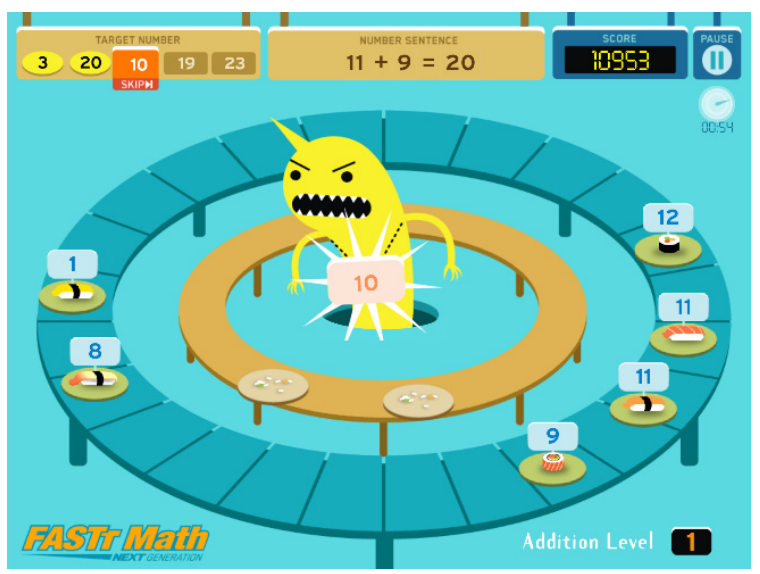

3. ábra: SushiMonster (Scholastic inc.) dó - és összeg - kerül a futószalagra.

A játék fejlesztői nem csak az összeadást szeretnék sushi szörnyek segítségével gyakoroltatni, hanem a szorzást is. Itt az adott szorzathoz kell a szorzó tényezőket kiválogatni az asztalról. A szerzők kizárólag kéttényezős szorzatokat várnak a megoldás során! Ez a játék a második pályától már inkább negyedik osztályosok számára lesz megfelelő, hiszen a szorzatok esetenként az ezres nagyságrendet is meghaladják. Ahogy nő a mennyiség, úgy lesz egyre nehezebb a tagok illetve a tényezők kiválasztása. 


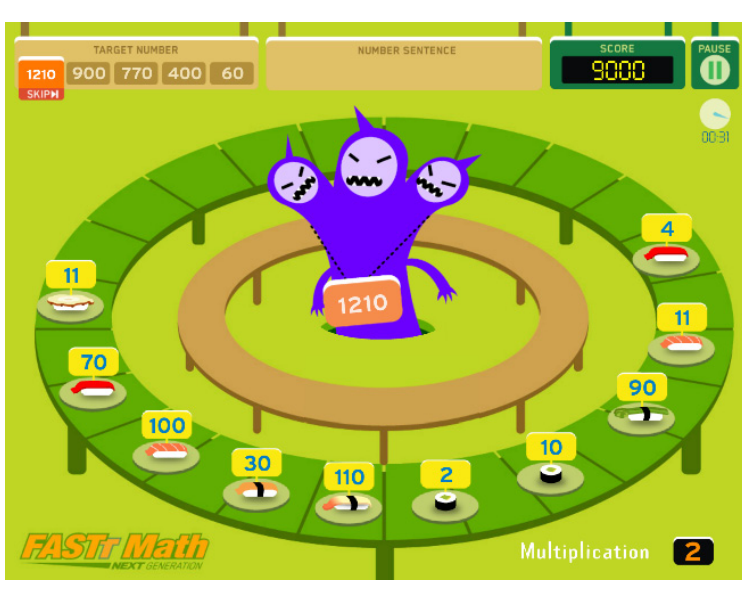

4. ábra: SushiMonster (Scholastic inc.)

$A$ játékok természetesen időre mennek. Az adott nehézségi szinten több pálya is található. Az egyes szintek eredményei összeadódnak: pont jár a gyorsaságért és a helyes válaszokért. Az összpontszámot a játék naplózza. A gyerekek úgy végzik a műveleteket egymás után, hogy észre sem veszik, hogy „matematikát gyakorolnak”, ők csak meg akarják dönteni saját illetve egymás rekordját!

A feladat elvégzéséhez szükséges készségek: gyors számforma-felismerés, gyors fejszámolás, jó reflex, megfelelő szem-kéz koordináció.

Hogy véletlenül se érhesse az a vád a játékok készítöit, hogy kizárólag az alsó tagozatra gondoltak, jöjjön egy tizenegyedikes témához kapcsolódó játék.

Ez a játék a gráfelmélet egy speciális kérdésköréhez kapcsolható. Ha feladat szöveget kellene hozzá írni, valahogy így szólna: „Az ábrán egy bejárható gráf látható,

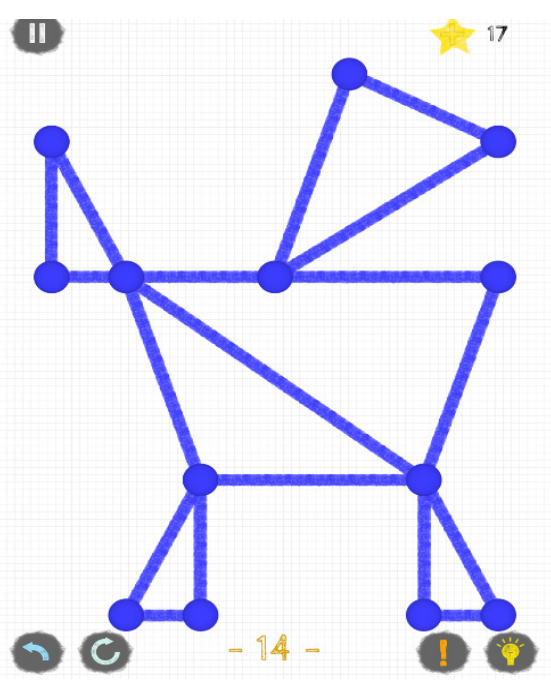

5. ábra: One touch Drawing (Ecapy inc.) add meg egy bejárását!"

Nyílván nem így fogalmazza meg a játék kitalálója a feladatot. Hanem úgy, hogy „Színezd át az összes vonalat, anélkül, hogy felemelnéd a ceruzádat. Minden vonalon azonban csak egyszer haladhatsz át!

A pályák nehézségi szintje az egészen egyszerütől az igen bonyolultakig terjed. A pontszám és az idő a játék során csillagok formájában öszszeadódik. Az ember a saját és a társai rekordjával versenyezhet.

A játéknak a korábbiakkal szemben nincs más fejlesztő hatása. Ugyanazt nyújtja, mit a tankönyvek és feladatgyüjtemények azonos típusú feladatai. A különbség csak annyi, hogy a játék izgalmas módon, versenyhelyzetet generálva gya-

koroltatja a kívánt tudást.

\section{Néhány analóg játék matematikaórára}

Készítsünk memóriajátékot az alábbi módon:

- az egyik kártyán szerepeljen egy szám, a másikon az összeg vagy szorzat formája;

- az egyik kártyán szerepeljen egy alakzat neve, a másikon a képe;

- az egyik kártyán egy függvény, a másikon a képe;

- az egyik kártyán 2 geometriai transzformáció, a másikon az az egy, amivel ez a kettő helyettesíthető;

- az egyiken egy gráf, a másikon egy fokszám sorozat stb.

Alkossanak a gyerekek párokat, és játsszanak ezekkel a kártyákkal klasszikus memóriajátékot. Az nyer, akinek sikerül a legtöbb párt megszereznie. A memória fejlesztésén túl fejlesztjük a játék során a megfigyelőképességet, a lényeges és lényegtelen információk szétválasztását, illetve a szociális kompetenciákat. 
Barkochbajáték matematikai objektumokkal. PI.: „Gondoltam egy

- számra,

- alakzatra,

- sokszögre,

- testre,

- egy függvényre",

és az ismert tulajdonságok rákérdezésével kitalálják a diákok. A játék játszható frontálisan, illetve csoportokban egyaránt. Minél több gyerek „gondol”, annál izgalmasabb a játék!

A játék során a szociális kompetenciák, a strukturált gondolkodás, a lényegeslényegtelen információk szürésének képessége egyaránt fejlődik.

\section{Összefoglalás}

Ebben a tanulmányban a szokásos tanulás-tanítási megközelítésektől eltérően, speciálisan matematikai szempontból közelítettem meg a Z- és az a-generáció tanulással kapcsolatos problémáját. Nem állítom, hogy a játékok és a digitális tananyagok használata automatikusan és okvetlenül didaktikai hasznot hozhat, vagy áthidaló szerepet játszhat ebben a kérdéskörben. Érdekesnek tartom azonban ennek vizsgálatát néhány tananyagrész, néhány eszköz és néhány digitális taneszköz kapcsán, különös tekintettel a motiváció kérdésére, az új tanári szerepre, a „függetlenebb tanulás” utáni vágyra, az együttmüködésre törekvésre. Ennek egy lehetséges útját mutattam be.

\section{Irodalom}

Pintér Róbert és Székely Levente (2006) Bezzeg a mai fiatalok - a tizenéves korosztály médiafogyasztása a többségi társadalom tükrében.(In: Internet.hu A magyar társadalom digitális gyorsfényképe 3.)

Guld Ádám és Maksa Gyula (2013) Kutatási jelentés. TÁMOP-4.2.3.-12/1/KONV-2012-0016 Tudománykommunikáció a Z-generációnak címü kutatás Fiatalok kommunikációjának megismerése alprojekt. Pécsi Tudományegyetem, Pécs.

Székely Levente (2010): Ifjúsági munka virtuális térben. In: Nagy Ádám dr., Földi László és Járosi Éva (2010, szerk.) Ifjúságügy - ifjúsági szakma, ifjúsági munka. Módszertani kézikönyv. ISzT-Mobilitás-ÚMK, Budapest.

Tari Annamária (2011): Z generáció, Tericum Kiadó Kft., Budapest. 